\title{
Miranda
}

Revue pluridisciplinaire du monde anglophone /

Multidisciplinary peer-reviewed journal on the English-

speaking world

15 | 2017

Lolita at 60 / Staging American Bodies

\section{Music and thrill(er)s: an interview with American novelist Peter Farris}

\section{Nathalie Vincent-Arnaud}

\section{OpenEdition}

\section{Journals}

\section{Electronic version}

URL: http://journals.openedition.org/miranda/11125

DOI: 10.4000/miranda.11125

ISSN: 2108-6559

Publisher

Université Toulouse - Jean Jaurès

\section{Electronic reference}

Nathalie Vincent-Arnaud, "Music and thrill(er)s: an interview with American novelist Peter Farris",

Miranda [Online], 15 | 2017, Online since 06 October 2017, connection on 16 February 2021. URL:

http://journals.openedition.org/miranda/11125 ; DOl: https://doi.org/10.4000/miranda.11125

This text was automatically generated on 16 February 2021.

\section{cc) (i) () $\Theta$}

Miranda is licensed under a Creative Commons Attribution-NonCommercial-NoDerivatives 4.0 International License. 


\title{
Music and thrill(er)s: an interview with American novelist Peter Farris
}

\author{
Nathalie Vincent-Arnaud
}

American novelist Peter Farris was in the south west of France at the end of September to attend two local literary festivals devoted to thrillers and noirs and promote his second, much-acclaimed, novel Ghost in the Fields, translated into French by Anatole Pons and published this year at Gallmeister's (http://www.gallmeister.fr/auteurs/ fiche/60/peter-farris). As a former musician, still deeply involved in music, he kindly and enthusiastically accepted to answer a few questions about the part played by this life-long passion of his in his writing.

Nathalie Vincent-Arnaud

Before you started writing fiction you were involved in a rock band for some time. Could you tell us briefly about the band and its main influences ? Do you still play music?

\section{Peter Farris}

I was vocalist (aka I screamed my head off) in a band from Connecticut called CABLE for about six years. I was actually a big fan of the band before I joined them, as CABLE had been recording and performing since the mid 90's. I recorded 3 full length records with the band (Never Trust A Gemini, Pigs Never Fly, The Failed Convict), and played dozens of shows over that span. We had a variety of influences, from Black Sabbath and Black Flag to Laughing Hyenas, Willie Nelson and Kyuss.

Nathalie Vincent-Arnaud

What made you turn to writing ? Could you tell us when and how that decision was made?

\section{Peter Farris}

It was a natural progression. I began writing lyrics and poetry, eventually attempting short fiction. My father was a novelist and he has always been an inspiration to me. Seemed inevitable I would fall in love with fiction writing. To pinpoint a particular moment or two, I believe I wanted to write novels when I discovered Flannery O'Connor and Larry Brown...paired with my experience during a bank robbery while working as a teller back in 2003. Those two writers and that experience planted the seed for my first novel Last Call for the Living. 
Nathalie Vincent-Arnaud

You used some lyrics from a previous song as an epigraph for your first novel; considering your music, do you consider this particular novel as some kind of « spin-off »?

\section{Peter Farris}

I think perhaps not a spin-off as much as two pieces of art that shared this kind of creative synergy. Our final record The Failed Convict was a concept album about a man who breaks out of Brushy Mountain State Prison in Tennessee. Given my first novel Last Call for the Living dealt with hardened criminals and prison gangs, it felt intuitive to link them by way of those epigraphs.

\section{Nathalie Vincent-Arnaud}

How much of your music, or of music in general, seems to you to be woven into your writing?

\section{Peter Farris}

Definitely quite a bit. I listen to music every waking second of the day, and particularly while I'm writing. I listen to everything, too...from dark jazz group Bohren \& Der Club of Gore, death metal, country music and film scores to Jason Molina and Nick Cave. In fact, each novel has a soundtrack...in my head anyway. There are even subtle (and not so subtle references) to some favorite artists sprinkled throughout Last Call for the Living and The Devil Himself.

Nathalie Vincent-Arnaud

Would you say that there is some kind of logical connection between rock music-or music in general-and thrillers?

\section{Peter Farris}

Absolutely. But I wouldn't limit the connection to rock music. A good thriller or noir should paint pictures in the head of the reader, and inspire certain attitudes and moods...just like a good metal song or dark ambient track.

Nathalie Vincent-Arnaud

If you were to go back to music as a main occupation one day, do you think that your approach to music would change because of your experience as a writer?

\section{Peter Farris}

Great question! During my time in CABLE, we made music that we wanted to hear. I think a musician or novelist (or filmmaker or painter, etc) should create art for themselves first and foremost. Follow your instincts and enjoy the process without regards to money, fame, ego or ambition. If it comes from an honest place-no matter your creative outlet-I guarantee people will respond to it.

\section{INDEX}

Subjects: Music

Keywords: music, noir, soundtrack, thriller

Mots-clés: musique, roman noir, soundtrack, thriller 


\section{AUTHORS}

\section{NATHALIE VINCENT-ARNAUD}

Professeur

Université Toulouse2-Jean Jaurès

nathalie.vincent-arnaud@univ-tlse2.fr 